\title{
Title: Comparative clinical study between lashuna and shatavari in minimizing the risk of postmenopausal osteoporosis
}

\section{Author: T. R. Thanga selva kumara* ${ }^{1}$, Mansi Modi ${ }^{2}$}

1. PG Scholar,

2. Associate Professor and H.O.D.,

Prasuti Tantra And Stri Roga Department,

Parul Institute of Ayurveda, Parul University, Limda, Waghodia, Vadodara, Gujarat.

*Corresponding Author: selvanakshathra@gmail.com, 9566535174

Abstract:

drugs lashuna and shatavari treated in comparison method. By its guna of

Ayurveda is one of the old traditional vatahara, rasayana etc.

science which deals with healthy and diseased state of human beings through lifestyle, dietary supplements, medication, yoga, purification techniques. In decades of old age can be reduced by the rasayana therapy, which is the line of treatment for vriddha age groups with dominant of vata dosha, agni mandya, dhatu and upadhatu Kshaya. Women are mostly vulnerable at early stage by the vata dosha, dhatu Kshaya especially asthi dhatu, upadhatu like aartava etc. Kshaya of asthi dhatu in menopausal period can be considered as menopausal osteoporosis. Prevention is better than cure as per this proverb, this study was held to prevent the risk of postmenopausal osteoporosis with the

Keyword:

rajonivritti, asthi kshaya, postmenopausal osteoporosis

\section{Aims and Objects}

- To assess the effect of lashuna in minimizing bone loss.

- To compare the efficacy of lashuna with shatavari. ..

\section{Materials and Methods:}

- The study was conducted on 40 women of menopausal age for a period of 12 weeks. Clinical features and objective parameters were documented before and after treatment. 
Statistical Analysis Used:

- Observations of the study were analyzed and findings were evaluated by using statistical methods (Student's $t$ test and un paired t test)

\section{Results:}

The present study shows that the trial drug lashuna tablet is effective to improve clinical features and objective parameters significantly. BMD was observed to statistically significant level $(\mathrm{p}<0.01)$ where as the rise in $\mathrm{x}$-ray and serum calcium were statistically $\quad$ significant $(\mathrm{p}<0.01)$.serum alkaline phosphatase data is not significant statistically $(p>0.05)$. In the group treated with shatavari tablet improvement was obtained in x-ray and serum calcium which were statistically significant $(\mathrm{p}<0.01)$. alkaline phosphatase data showe statistically insignificant improveme ( $\mathrm{p}$ 0.05).Improvement in parameters suggests lashuna tablet improves the calcium metabolism.

\section{Discussions:}

Madhura, tikta rasa, snigdha and guru guna, vatahara, balya, can be used to used to control asthidhatu Kshaya which will help for reducing risk of postmenopausal osteoporosis.

Lashuna encounters vata dosha which having the inter relation with asthidhatu by its madhura, snigdha, guru, vatahara guna.

Conclusion:

The results suggest that lahuna vati is significantly effective in the preventive aspect of post menopausal osteoporosis.

\section{Introduction:}

Osteoporosis may be defined as a reduction in bone mass per unit volume such that fractures may occur with minimal trauma. It is the most common metabolic bone disease in the Western world. There are many causes, but by far the most common and most important is postmenopausal osteoporosis, which affects most women by the end of their lives ${ }^{\mathrm{i}}$. Despite an increasing awareness of the importance of osteoporosis in some sections of the population, many women are still not sufficiently aware of the condition, do not appreciate the way in which it may affect their lives and, most importantly, do not understand that it is preventable. It is the duty of healthcare professionals to provide women with an impartial account of the current knowledge garding osteoporosis ${ }^{\mathrm{ii}}$.

months. During young stage the female are protected by female hormone i.e. oestrogen and progesterone in Menopause females are enters in oestrogen deficient in their lives, it in one year ageing process along with psychosomatic problems. Old age is vulnerable time for both men and women but for women it is even more. ${ }^{\mathrm{iii}}$ So, in addition to process of senility, women suffer simultaneously from the inevitable scars of Menopause.

In the present study, has taken for the study, where there will be decrease in the density of the bone tissue. The term "Osteoporosis" was coined by Pommer in 1885 which literally means "porous bones".

Osteoporosis is defined as "a disease in Asthi - Kshaya which the density and quality of the bone are reduced, leading to 
weakness of the skeleton and increased risk of fracture, particularly of the spine, wrist and hip". In 1994 World Health Organization defined Osteoporosis as "a systemic skeletal disease characterized by low bone mass and bone architectural leading to increased risk"iv ${ }^{\text {"iv }}$ Menopause is normal process but now a day it becoming major health problem in developing countries like India. Osteoporosis has haunted women since the dawn of history. Egyptian mummies from 4,000 years ago have been found with the tell-tale dowager's hump. Osteoporosis is a major international health problem, accentuated by increasing longevity. Osteoporosis is estimated to affect 200 million.

The number of women with osteoporosis, i.e., with reduced bone mass and the disruption of bone architecture, is increasing in India. While data prevalence of osteoporosis among wom in India come from studies conducted small groups spread across the country, estimates suggest that of the 230 million Indians expected to be over the age of 50 years in $2015,20 \%$, i.e., 46 million, are with osteoporosis ${ }^{\mathrm{v}}$. Thus, osteoporosis is a major public health problem in Indian women.

The risk even increases at Menopause, which is a physiological transition period of hormonal imbalance. In Ayurveda Menopause deals with jarapakvaavasta of the body. Jara and Rajonivritti are manifested due to progressive reduction in the functional ability of agnis, which results into an inadequate tissue nutrition. This nutritional imbalance triggers the irreversible degenerative changes in "Sapta Dhatus". The disease Osteoporosis is somewhat similar to description of Asthi
Kshaya in which metabolism of Asthi Dhatu is disturbed. Rasayana therapy has proved efficacious in managing and preventing many chronic conditions till date. As Postmenopausal Osteoporosis is a disease related to aging.

Rasayana can provide better alterative in increasing quality of life. Here, the drug Lashuna also one of the Rasayana guna dravya.Due to (properties as heavy \& general rasas (tastes), Lashuna cures common diseases, increases longevity, is appetiser, aphrodisiac blessed or fortunate and foremost for disease-free state. It is clarifier of memory, intellect, strength, age (longevity), complexion \& eyes (sight), producer of good smell in mouth, cleaner of the channels. In dislocation, fracture \& diseases of bones, in the persons suffering from all diseases of vata are indicated by qshuna.

\section{ims_and_Objects:}

To study the disease postmenopausal osteoporosis - as per Ayurveda and modern concept. To assess the effect of lashuna in minimizing bone loss.

To compare the efficacy of lashuna with shatavari.

\section{Material andan Methods}

The study was conducted on 40 women of menopausal age for a period of 12 weeks. Clinical features and objective parameters were documented before and after treatment.

\section{Observations:}

$62.5 \%$ patients were belonged to $46-50$ age group, $15 \%$ were 51-55and 56-60 age group each, $7.5 \%$ were $40-45$ age group. 
Maximum $62.5 \%$ of patients were Perimenopausal and $37.5 \%$ were postmenopausal on registration. $37.5 \%$ patients were belonged to the duration of $<2$ years of menopause, $22.5 \%$ were between 4 to 6 years ,25\% were between 2 to 4 years, $15 \%$ were $>6$ years. $52.5 \%$ patients had menopause between the age of 46-50 years, $32.5 \%$ patients were between 51-55 years , $12.5 \%$ patients were between 40-45 years ,2.5\% patients were between 56-60 years. 100 percentage of patients were married. $37.5 \%$ patients had primary education, $32.5 \%$ patients were uneducated ,20\% patients had secondary education, $10 \%$ patients had higher secondary education. $30 \%$ patients were lower middle class, $27.5 \%$ were poor \& middle class each, $15 \%$ were upper middle class. $82.5 \%$ patients were belonged to rural, $17.5 \%$ patients were belonged to urban. $67.5 \%$ ,32.5\% of patients had irregular and regula menses respectively .Quantity of mens was excess ,moderate and scanty for $50 \%$ $, 37.5 \%, 12.5 \%$ of patients respectively .Duration of mense majority $42.5 \%$ were observed in 2-3 days ,40\% were observed in >3days, $17.5 \%$ were observed in $1-2$ days $.50 \%, 30 \%, 20 \%$ of patients had 2-4, $4-6,0-2$ months period of interval respectively. $100 \%$ of patients were observed in multi-parity. $62.5 \%$ of patients were belonged to vegetarian and $37.5 \%$ of patients were under mixed diet. $65 \%$ of patients were habited for vishamasana, and $35 \%$ of them were samsanain dietetic habit. $77.5 \%$ of patients were having raja manasa prAkriti , $15 \%$ of patients were having tama manasa prakriti ,7.5\% were having satvamanasa prakriti. $100 \%$ of patients were belonged to praudha. $67.5 \%, 32.5 \%$ of patients were presented with avaraand madhyama Vyayamashakti respectively.
Among 40 patients $97.5 \%, 77.5 \%, 37.5 \%$, $27.5 \%, 15 \%$ of patients has the complains of asthivedana, katishoola, sandhishoola, shrama, keshapadanarespectively.

\section{Results:}

In patients treated with lashuna tablet BMD was observed to statistically significant level $(\mathrm{p}<0.01)$ where as the rise in $\mathrm{x}$-ray and serum calcium were statistically significant $\quad(p<0.01)$. Serum alkaline phosphatase data is not significant statistically $(p>0.05)$. In the group treated with shatavari tablet improvement was obtained in $\mathrm{x}$-ray and serum calcium which were statistically significant $(\mathrm{p}<0.01)$. alkaline phosphatase data showed statistically insignificant improvement ( $p>0.05)$.Improvement in parameters suggests lashuna tablet improves the calcium metabolism.

majority of patients, markers of bone formation and bone resorption were in normal range. Yet they were used to judge the effect of therapy on bone turnover.

When compared with group A and group B .Group A had better relief in symptoms of asthivedana but on comparison shows statistically insignificant (>0.05). In katishoola group A $85.7 \%$ of relief was found but group B had $62.5 \%$ of relief on comparison both groups the data is statistically insignificant $\quad(p>0.05)$ on symptoms of sandhishoola group B $89.1 \%$ had better result when compared to group A $(72.9 \%)$ and the inter statistical shows significant data $(<0.001)$. Shrama group B $86.4 \%$,group A $72.2 \%$ group B had better relief percentage and the inter statistical data shows significant data $(<0.001)$ and keshapadana group A $76.1 \%$, group B $75 \%$ group A had better result when compared 
to group B and the inter statistical data is significant $(\mathrm{p}<0.05)$.

Better result was found in group A in x-ray $67.5 \%$, serum calcium $18.6 \%$ but inter statistical found to be in significant and insignificant respectively .on all other features like BMD 61.4\%, alkaline phosphatase $3 \%$ in group $\mathrm{B}$ but interstatistical data found to be in significant $(\mathrm{p}>0.05)$.

The present study shows that the trial drug lashuna is effective than standarad group shatavari group .But interstatastical analysis shows insignificant results. No adverse effect of the trial drug was observed during the study.

\section{Discussions:}

Tablet form of those two groups (lashuna and shatavari) were had result, but it is not possible to take raw drug regularly, tablet is easy to take daily.

Madhura, tikta rasa, snigdha and guru guna, vatahara, balya, can be used to used to control asthidhatu Kshaya which will help for reducing risk of postmenopausal osteoporosis.

Lashuna encounters vata dosha which having the inter relation with asthidhatu by its madhura, snigdha, guru, vatahara guna.

After 3 months of treatment it was observed that, in Group A(lashuna tablet) $21 \%$ patients got marked improvement, $52.6 \%$ patients got moderate improvementand $21 \%$ patients mild improvement. In Group B (shatavari tablet) $20 \%$ patients got marked improvement, $60 \%$ patients got moderate improvement, and $20 \%$ patientsgotmild improvement.S

\section{Conclusion:}

1. Women's during their post menopausal age were vulnerable to osteoporosis

2. Due to aging process women were naturally developed decline on bone formations.

3. The disease entity postmenopausal osteoporosis was not described in classics of Ayurveda, it shows decline is due to the aging process of human life that which is taken over by the dominant of vata dosha and having the seat of asthi dhatu which leads to the asthi Kshaya.

4. Postmenopausal period diseases were not mentioned directly in any of the ayurvedic reference due to its kalaja nidana as a natural progress of the human life.

5. Especially for menopausal diseases like osteoporosis mostly the treatment should be based on HRT.

6. During rajonivritti period mostly the vyadhis were vataja, that which is unfavourable for all the dhatus especially asthi dhatu, which leads to Kshaya 
7. Due to the vayu prakopa and the Kshaya of asthi dhatu leads to the symptoms like asthivedana, kativedana.

8. Due to the involvement of gambhira dhatu it needs continuous supply of poshaka dravyas in the form of rasayana.

9. The drug lashuna had given a satisfied results on bone markers that which gives idea about the effect of drug on the bone.

10. The rasa, guna, prabhava, karma of lashuna had broken down the Samprapti that which reduces the vata vriddhi and asthi Kshaya.

11. Hence, it can be concluded that in women at the risk of post menopausal osteoporosis and the symptoms of menopausal syndrome, lashuna gives better result

\section{ALTERNATIVE}

HYPOTHESIS(H1) is accepted as the trial drug significantly proved lashuna prayoga has effect on postmenopausal osteoporosis than the control drug shatavari.

\section{Acknowledgement:}

It is indeed a pleasuring privilege for me to express my gratefulness my gratitude with profound respect to my Guide Dr. Mansi Modi assistant Prof. \& HOD, Department Of Prasooti Tanta And StreeRoga, Parul Institute Of Ayurved, Vadodara for her insurmountable enthusiasm, continuous inspiration, suggestions and moral support throughout

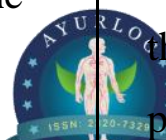

he course of this study. It is really a Leasure for me that she has provided me an opportunity to complete this work under her kind patronage and guidance.

\section{Ethical committee permissions details:}

IEC No: PIA/IECHR/2016-17/PTSR/06

\section{References:}

i. Riggs BL, Melton LJ. Involutional osteoporosis. N Engl J Med 1986; 314: 1676-86.

ii. Melton L. J. III. Etiology, diagnosis and management. In: Riggs B, Melton LI, eds. Epidemiology of Fractures. New York: Raven Press, 1988: 133-54.

iii. National Osteoporosis Foundation. America's Bone Health: The State of Osteoporosis and Low Bone Mass in Our Nation. Washington, DC: National Osteoporosis Foundation, 2002. 
iv. Melton LJ 3rd, Chrischilles EA, Cooper C, Lane AW, Riggs BL. Perspective. How many women have osteoporosis? J Bone Miner Res 1992; 7: 1005-1010.

v. National Osteoporosis Foundation. Disease statistics. http://www.nof.org/osteoporosis/stats.htm.

vi. $\quad$ Riggs BL, Melton LJ. Involutional osteoporosis. N Engl J Med 1986; 314: 1676-86.

vii. Melton L. J. III. Etiology, diagnosis and management. In: Riggs B, Melton LI, eds. Epidemiology of Fractures. New York: Raven Press, 1988: 133-54.

viii. National Osteoporosis Foundation. America's Bone Health: The State of Osteoporosis and Low Bone Mass in Our Nation. Washington, DC: National Osteoporosis Foundation, 2002.

ix. Melton LJ 3rd, Chrischilles EA, Cooper C, Lane AW, Riggs BL. Perspective. How many women have osteoporosis? J Bone Miner Res 1992; 7: 1005-1010.

x. National Osteoporosis Foundation. Disease statistics. http://www.nof.org/osteoporosis/stats htm.

\section{Cite article:}

Comparative clinical study between lashuna and shatavari in minimizing the risk of postmenopausal osteoporosis 